\title{
PENGKONSTRUKSIAN KONSEP FISIKA MELALUI PEMBELAJARAN STUDENT TEAMS ACHIEVEMENT DIVISION (STAD)
}

\author{
Abdul Faqih \\ FKIP UT Kampus C Unair Mulyorejo Surabaya 60115
}

\begin{abstract}
Abstrak
Berdasarkan hasil observasi yang dilakukan peneliti berkolaborasi dengan guru di SMA 2 Mojokerto didapatkan bahwa perlu membantu siswa untuk menemukan sendiri konsep fisika dan memperoleh pemahaman yang lebih mendalam dan bermakna. Peneliti mencoba menerapkan suatu pembelajaran agar pembelajaran lebih menarik yaitu dengan pendekatan konstruktivis melalui pembelajaran kooperatif tipe STAD terhadap hasil belajar fisika materi Listrik dinamis di SMA 2 Mojokerto. Rancangan penelitian ini adalah True Experimental design dengan replikasi. Sampel penelitian kelas diambil 3 kelas. Dari hasil analisis uji-t dua pihak didapatkan $t_{\text {hitung }}$ berturut-turut kelas $X_{A}$, dan $X_{B}$ sebesar 4,6 dan 3,26 dengan $t_{\text {tabel }}$ sebesar 2,00. Hal ini menunjukkan bahwa rata-rata hasil belajar kelas eksperimen yaitu kelas $\mathrm{X}_{\mathrm{A}}$ dan kelas $\mathrm{X}_{\mathrm{B}}$ berbeda dengan kelas kontrol. Hasil uji-t satu pihak didapatkan $t_{\text {hitung }}$ berturut-turut kelas $X_{A}$ dan $X_{B}$ sebesar 4,6 dan 3,26 dengan $t_{\text {tabel }}$ sebesar 1,67. Hal ini menunjukkan bahwa rata-rata hasil belajar kelas eksperimen yaitu kelas $\mathrm{X}_{\mathrm{A}}$ dan kelas $\mathrm{X}_{\mathrm{B}}$ lebih baik daripada kelas kontrol. Dapat disimpulkan bahwa pendekatan konstruktivis melalui model pembelajaran kooperatif tipe STAD berpengaruh positif terhadap pengkonstruksian konsep fisika berupa hasil belajar fisika materi Listrik Dinamis siswa X SMA 2 Mojokerto
\end{abstract}

Kata kunci: pengkonstruksian konsep, pembelajaran STAD. 


\section{Pendahuluan}

Fisika merupakan salah satu cabang IPA yang mendasari perkembangan teknologi maju dan konsep hidup harmonis dengan alam yang perlu mendapatkan perhatian tersendiri karena belajar fisika bukan hanya belajar berhadapan dengan teori, rumus atau dengan menghafal saja melainkan harus berbuat sesuatu, mengalami dan memecahkan persoalan dengan segala aspek yang berkaitan dengannya (Depdiknas,2006).

Pemahaman konsep siswa pada suatu materi pelajaran merupakan faktor yang tidak mudah untuk diatasi. Agar konsep tertanam kuat dalam benak siswa, maka diperlukan pengelolaan pengajaran yang baik. Pengelolaan pengajaran yang baik harus dikembangkan berdasarkan prinsipprinsip pengajaran. Prinsip mengajar merupakan usaha guru dalam menciptakan dan mengkondisikan situasi belajar mengajar agar siswa melakukan kegiatan belajar secara optimal. Penggunaan prinsip mengajar bisa direncanakan guru pada saat berlangsungnya proses belajar mengajar, bisa juga secara spontan dilaksanakan pada saat berlangsungnya proses belajar mengajar, terutama bila kondisi belajar siswa sudah menurun. Suatu pengajaran disebut berjalan dan berhasil dengan baik, jika guru mampu mengubah diri siswa, dan mampu menumbuhkan kesadaran siswa untuk belajar, sehingga pengalaman yang diperoleh siswa selama ia terlibat di dalam proses pengajaran itu dapat dirasakan manfaatnya secara langsung bagi perkembangan pribadinya (Rohani A, 2004).

Pembelajaran fisika masih perlu berbenah dan menuju penerapan pembelajaran yang inovatif dan siswa diajak menemukan sendiri konsep fisika yang nantinya akan membantu siswa untuk memperoleh pemahaman yang lebih mendalam sehingga siswa memiliki keterampilan dalam mencari tahu konsep tersebut. Hal itu dapat diketahui dari hasil belajar fisika siswa kelas $\mathrm{X}$ di SMA 2 yang mencapai Standar Ketuntasan
Minimun (SKM) masih sebesar 50\%, sedangkan $50 \%$ yang lainnya masih belum mencapai Standar Ketuntasan Minimum (SKM), untuk mengatasi beberapa siswa yang belum mencapai SKM guru umumnya memberikan tugas kepada siswa atau yang dikenal dengan remidi, hal ini dirasakan kurang efektif karena dengan remidi siswa hanya memperbaiki nilai saja tanpa memperbaiki pemahaman serta keterampilan berfikir siswa.

Berdasarkan masalah di atas, diperlukan pembelajaran untuk meningkatkan kemampuan pengkonstruksian konsep fisika yang berpengaruh terhadap peningkatan hasil belajar siswa kelas $\mathrm{X}$ di SMA 2. Hal ini dapat dilakukan dengan menggunakan pendekatan konstruktivis, yaitu pendekatan belajar yang menekankan peran atau keaktifan dalam membentuk pengetahuan siswa. Dalam pendekatan konstruktivis siswa harus membangun pengetahuan di dalam benaknya sendiri dari suatu informasi khusus sampai hal kompleks. Konstruktivis mempunyai berbagai kelebihan, antara lain dapat menumbuhkan minat atau motivasi siswa, serta menemukan fakta atau konsep sendiri melalui bimbingan guru. Dalam pendekatan ini siswa dilatih untuk dapat menerapkan pengetahuan serta memecahkan masalah dan menemukan sesuatu untuk dirinya sendiri sebagaimana pandangan teori konstruktivis.

Selain itu, untuk mengatasi masalah di atas dapat juga diterapkan model pembelajaran agar pendekatan konstruktivis dapat berjalan. Salah satu model pembelajaran yang berorientasi pada teori konstruktivis adalah model pembelajaran kooperatif salah satunya tipe STAD. Beberapa ahli menyatakan bahwa model ini tidak hanya membantu siswa memahami konsep-konsep sulit, tetapi berguna juga untuk menumbuhkan kemampuan kerjasama, berfikir kritis, serta mampu untuk mengembangkan sikap sosial siswa.

Berdasarkan latar belakang di atas penulis ingin menerapkan pembelajaran 
konstruktivis untuk membantu siswa mengkonstruksi konsep fisika, sehingga melalui penelitian ini diharapkan juga motivasi siswa untuk belajar fisika bertambah dan guru dapat menemukan pola pengajaran yang tepat.

\section{Rumusan Masalah}

- Bagaimana pengaruh pendekatan konstruktivis melalui model pembelajaran kooperatif tipe STAD terhadap pengkonstruksian konsep fisika berupa hasil belajar siswa kelas X SMA 2 Mojokerto?

- Bagaimanakah perbandingan aspek afektif dan aspek psikomotor dalam pengkonstruksian konsep fisika kelas eksperimen dibanding dengan kelas control?

\section{Tujuan}

Mendeskripsikan pengaruh pendekatan konstruktivis melalui model pembelajaran kooperatif tipe STAD terhadap pengkonstruksian konsep fisika berupa hasil belajar siswa kelas $\mathrm{X}$ SMA 2 Mojokerto dan aspek afektif dan psikomotor.

\section{Manfaat Penelitian}

Adapun manfaat dari penelitian ini adalah tersedia alternatif suatu model pembelajaran dan metode pembelajaran yang berguna untuk meningkatkan hasil belajar siswa melalui pengkonstruksian konsep fisika pada materi pokok listrik dinamis.

\section{Metode Penelitian}

Desain yang digunakan dalam penelitian ini menggunakan True Experiment Design, dengan jenis Control group pretes-postes.Dengan rancangan yang dapat dibagankan sebagai berikut:

Tabel 1. Desain Penelitian

\begin{tabular}{|l|c|c|c|}
\hline \multicolumn{1}{|c|}{ Kelas } & Pre-test & Perlakuan & Post-test \\
\hline Eksperimen I & $\mathrm{P}_{1}$ & $\mathrm{~L}_{1}$ & $\mathrm{P}_{2}$ \\
\hline Eksperimen II & $\mathrm{P}_{1}$ & $\mathrm{~L}_{1}$ & $\mathrm{P}_{2}$ \\
\hline Kontrol & $\mathrm{P}_{1}$ & - & $\mathrm{P}_{2}$ \\
\hline
\end{tabular}

Keterangan :

$\mathrm{P}_{1}$ : Pretes

$\mathrm{L}_{1}$ : Perlakuan, yaitu siswa diberikan materi listrik dinamis dengan pembelajaran konstruktivis dengan model kooperatif tipe STAD.

$\mathrm{P}_{2}$ : Postes (Suharsimi Arikunto, 2002)

Populasi penelitian ini adalah siswa kelas X SMA 2 Mojokerto, Sampel yang digunakan dalam penelitian ini adalah kelas $\mathrm{X}_{\mathrm{A}}, \mathrm{X}_{\mathrm{B}}$ dan $\mathrm{X}_{\mathrm{C}}$, pengambilan kelas tersebut dengna pertimbangan karena pendistribusian siswa tiap kelas merata berdasarkan nilai semester.

Variabel bebas adalah variabel yang sengaja dipelajari pengaruhnya terhadap variabel terikat. Dalam penelitian ini yang menjadi variabel bebas adalah pembelajaran konstruktivis melalui model pembelajaran kooperatif tipe STAD. Variabel terikat adalah hasil yang didapat setelah perlakuan. Dalam penelitian ini adalah hasil belajar siswa dari pengkonstruksian konsep fisika, kemam- puan afektif dan psikomotor dan respon siswa. Variabel kontrol adalah variabel yang dijaga agar tidak mengganggu selama penelitian, variabel kontrol yang digunakan dalam penelitian adalah materi pelajaran, guru, dan kemampuan siswa.

Instrumen penelitian yang digunakan berupa lembar tes hasil belajar, lembar pengamatan keterlaksanaan rencana pembelajaran, lembar pengamatan guru dan siswa, lembar penilaian kinerja psikomotor, lembar penilaian afektif dan angket respon siswa.

Metode pengumpulan data dengan metode observasi dan metode tes. Metode observasi yang dilakukan penelitian ini dengan menggunakan lembar pengamatan 
yang diperoleh waktu kegiatan pembelajaran berlangsung, baik siswa mapun guru. Metode tes adalah serentetan pertanyaan atau latihan serta alat lain yang digunakan untuk mengukur pengetahuan, integelensi, keterampilan atau bakat yang dimiliki oleh individu atau kelompok. Angket adalah sejumlah pertanyaan tertulis yang digunakan untuk memperoleh informasi dari respon pembelajaran selama proses belajar mengajar. Angket respon siswa digunakan untuk mengetahui respon siswa terhadap pembelajaran fisika menggunakan pendekatan konstruktivis dengan model pembelajaran kooperatif tipe STAD.

Metode Analisis Data terdiri dari analisis butir soal meliputi validitas soal, reliabilitas, tingkat kesukaran, dan daya pembeda. Analisis data penelitian menggunakan uji-t. Terlebih dahulu dilaksanakan analisis tentang normalitas dan homogenitas yang dikenakan pada skor pre-test dan post-test. Uji Hipotesis dengan Uji-t dua pihak. Uji ini digunakan untuk mengetahui apakah terdapat perbedaan hasil belajar siswa dengan menggunakan STAD dengan hasil belajar siswa tanpa STAD. Data yang digunakan adalah data post-test baik kelas eksperimen maupun kelas kontrol. Uji-t satu pihak digunakan untuk mengetahui manakah hasil belajar yang lebih baik antara kelas eksperimen dan kelas kontrol.

Analisis Regresi adalah hubungan yang dinyatakan dalam bentuk persamaan metematik yang menyatakan hubungan fungsional antara variabel-variabel. Penelitian ini akan ditentukan persamaan regresi $\mathrm{Y}$ atas $\mathrm{X}$, dengan $\mathrm{X}$ adalah konstruktivis dalam pembelajaran STAD dan Y adalah kemampuan aspek kognitif siswa pengkonstruksian soal berupa hasil belajar, maka regresi berdasarkan sampel adalah $\mathrm{Y}=\mathrm{a}+\mathrm{bX}$.

Apabila garis regresi yang terbaik untuk sekumpulan data berbentuk linier, maka derajat hubungan akan dinyatakan dengan $r$ dan bisa dinamakan koefisien korelasi. Untuk keperluan perhitungan koefisien korelasi $\mathrm{r}$ berdasarkan sekumpulan data $\left(\mathrm{X}_{\mathrm{i}}, \mathrm{Y}_{\mathrm{i}}\right)$ berukuran $\mathrm{r}$ dapat digunakan rumus korelasi product moment (Sudjana, 1989).

\section{Hasil dan Pembahasan}

\section{Hasil uji normalitas dan homogenitas}

Berdasarkan hasil pretest dapat diketahui kemampuan awal siswa sehingga diperoleh hasil yang dapat digunakan untuk mengetahui uji normalitas dan uji homogenitas sampel yang dipilih. Berdasarkan perhitungan diperoleh hasil uji normalitas untuk masing-masing sampel dapat ditulilskan dalam tabel 2 sebagai berikut:

Tabel 2. Hasil Perhitungan uji Normalitas

\begin{tabular}{|l|c|l|}
\hline $\begin{array}{c}\text { Kelas / } \\
\text { Sampel }\end{array}$ & $\begin{array}{c}\mathrm{X}^{2}{ }_{\text {hitun }} \\
\mathrm{g}\end{array}$ & $\begin{array}{l}\mathrm{X}_{\text {tab }}^{2} \\
\text { el }\end{array}$ \\
\hline $\begin{array}{l}\text { Eksperim } \\
\text { en 1 / } \mathrm{X}_{\mathrm{A}}\end{array}$ & 2,2 & 11,1 \\
\hline $\begin{array}{l}\text { Eksperim } \\
\text { en 2 / } \mathrm{X}_{\mathrm{B}}\end{array}$ & 1,8 & 11,1 \\
\hline $\begin{array}{l}\text { Kontrol / } \\
\mathrm{X}_{\mathrm{C}}\end{array}$ & 6,4 & 11,1 \\
\hline
\end{tabular}

Sampel dapat dikatakan berdistribusi normal, jika $\mathrm{X}_{\text {hitung }}^{2}<\mathrm{X}_{\text {tabel. }}^{2}$ Berdasarkan tabel di atas maka dapat disimpulkan bahwa keempat sampel adalah berdistribusi normal dengan taraf signifikan $\alpha=0,05$ atau dengan taraf kepercayaan sebesar 95\%. Hasil uji homogenitas untuk masing-masing sampel dapat dituliskan dalam tabel 3 sebagai berikut:

Tabel 3. Hasil Perhitungan Homogenitas

\begin{tabular}{|c|c|c|c|c|c|c|}
\hline Sampel & $\mathrm{n}_{\mathrm{i}}$ & $\mathrm{S}_{\mathrm{i}}{ }^{2}$ & $\mathrm{~S}_{\mathrm{gab}}$ & $\mathrm{B}$ & $\mathrm{X}_{(1-0,05)(4-1)}$ & $\mathrm{X}_{\text {hitung }}{ }^{2}$ \\
\cline { 1 - 3 } Eks 1 & 34 & 130,23 & & & & \\
\cline { 1 - 3 } Eks 2 & 34 & 145,97 & & & & \\
\cline { 1 - 3 } Kontrol & 36 & 47,54 & 106,72 & 204,83 & 7,81 & 5,12 \\
\hline
\end{tabular}


Sampel dikatakan homogen, jika $\mathrm{X}_{\text {hitung }}^{2}$ $\mathrm{X}_{\text {tabel. }}^{2}$ Berdasarkan tabel diatas maka dapat disimpulkan bahwa keempat sampel adalah homogen dengan taraf signifikan $\alpha$ $=0,05$ atau dengan taraf kepercayaan sebesar $95 \%$. Nilai posttest merupakan hasil belajar siswa setelah menerima materi. Nilai mean, simpangan baku, dan jumlah siswa dari 3 kelas eksperimen dapat dituliskan pada tabel 4 sebagai berikut:

Tabel 4. Hasil Perhitungan $\bar{x}, \mathrm{~S}^{2}$, dan $\mathrm{n}$ dari hasil belajar siswa

\begin{tabular}{|l|c|c|c|}
\hline \multicolumn{1}{|c|}{ Kelompok } & $\bar{x}$ & $\mathbf{S}^{\mathbf{2}}$ & $\mathbf{N}$ \\
\hline Kelas Eksperimen 1 / $\mathrm{X}_{\mathrm{A}}$ & 72,36 & 73,70 & 34 \\
\hline Kelas Eksperimen 2 / $\mathrm{X}_{\mathrm{B}}$ & 68,53 & 95,05 & 34 \\
\hline Kelas Kontrol / $\mathrm{X}_{\mathrm{C}}$ & 62,72 & 76,38 & 36 \\
\hline
\end{tabular}

Dari hasil belajar siswa tersebut dibandingkan antara masing-masing kelas eksperimen dengan kelas kontrol yaitu melalui uji-t dua pihak dan uji-t satu pihak.
Setelah dianalisis dengan uji-t dua pihak didapatkan nilai $\mathrm{t}$ untuk masing-masing sampel dapat dituliskan pada tabel 5 sebagai berikut:

Tabel 5. Hasil Uji-t dua pihak

\begin{tabular}{|l|c|c|}
\hline \multicolumn{1}{|c|}{ Kelas } & $\mathrm{t}_{\text {hitung }}$ & $\mathrm{t}_{\text {tabel }}$ \\
\hline K. Eks 1/ $\mathrm{X}_{\mathrm{A}}$ dengan K Kontrol / $\mathrm{X}_{\mathrm{C}}$ & 4,6 & 2,00 \\
\hline K. Eks 2/ X $\mathrm{B}$ dengan K Kontrol / $\mathrm{X}_{\mathrm{C}}$ & 2,26 & 2,00 \\
\hline
\end{tabular}

Jika hipotesis yang diajukan Ho : $\mu_{1}=\mu_{2}$ ,maka rata-rata hasil belajar antara kelas eksperimen dan kelas kontrol adalah sama tetapi jika $\mathrm{H}_{1}: \mu_{1} \neq \mu_{2}$, maka rata-rata hasil belajar antara kelas eksperimen dan kelas kontrol adalah berbeda, dimana kriteria penarikan hipotesis adalah terima Ho jika $t_{\text {hitung }}<t_{(1-1 / 2 \alpha)}$ atau $t_{\text {hitung }}<t_{\text {tabel }}$ dan tolak Ho jika $t_{\text {hitung }}>t_{(1-1 / 2 \alpha)}$ atau $t_{\text {hitung }}>$ $t_{\text {tabel}}$, dengan derajat kebebasan untuk derajat distribusi $\mathrm{t}$ adalah $\left(\mathrm{n}_{1}+\mathrm{n}_{2}-2\right)$ dengan peluang $(1-1 / 2 \alpha)$. Berdasarkan nilai
Uji-t dua pihak dan kriteria penarikan hipotesis dari tabel 5 di atas terlihat bahwa 2 kelas ekperimen yaitu kelas $X_{A}$ dan kelas $\mathrm{X}_{\mathrm{B}}$ menunjukkan bahwa rata-rata hasil belajar siswa kelas eksperimen berbeda dengan rata-rata hasil belajar kelas kontrol karena ( $\left.t_{\text {hitung }}>t_{\text {tabel }}\right)$.

Setelah dianalisis dengan uji-t satu pihak didapatkan nilai $t$ untuk masingmasing sampel dapat dituliskan pada tabel 6 sebagai berikut:

Tabel 6. Hasil Uji-t satu pihak

\begin{tabular}{|l|c|c|}
\hline \multicolumn{1}{|c|}{ Kelas } & $\mathrm{t}_{\text {hitung }}$ & $\mathrm{t}_{\text {tabel }}$ \\
\hline K. Eks 1/ $\mathrm{X}_{\mathrm{A}}$ dengan K Kontrol / $\mathrm{X}_{\mathrm{C}}$ & 4,6 & 1,67 \\
\hline K. Eks 2/ $\mathrm{X}_{\mathrm{B}}$ dengan K Kontrol / $\mathrm{X}_{\mathrm{C}}$ & 2,26 & 1,67 \\
\hline
\end{tabular}

Jika hipotesis yang diajukan Ho : $\mu_{1}=\mu_{2}$, maka rata-rata hasil belajar antara kelas eksperimen dan kelas kontrol adalah sama tetapi jika $\mathrm{H}_{1}: \mu_{1}>\mu_{2}$, maka rata-rata hasil belajar antara kelas eksperimen lebih baik daripada rata-rata hasil belajar kelas kontrol, dimana kriteria penarikan hipotesis adalah terima Ho jika $\mathrm{t}_{\text {hitung }}<\mathrm{t}_{(1-\alpha)}$ atau $t_{\text {hitung }}<t_{\text {tabel }}$ dan tolak Ho jika $t_{\text {hitung }}>$ $t_{(1-\alpha)}$ atau $t_{\text {hitung }}>t_{\text {tabel }}$, dengan derajat kebebasan untuk derajat distribusi $\mathrm{t}$ adalah $\left(\mathrm{n}_{1}+\mathrm{n}_{2}-2\right)$ dengan peluang $(1-\alpha)$. Berdasarkan nilai uji-t satu pihak dan kriteria penarikan hipotesis dari tabel $4.5 \mathrm{di}$ atas terlihat bahwa 2 kelas ekperimen yaitu kelas X B dan kelas X A menunjukkan bahwa rata-rata hasil belajar siswa kelas eksperimen lebih baik daripada rata-rata 
hasil belajar kelas kontrol karena ( $t_{\text {hitung }}>$ $\left.t_{\text {tabel }}\right)$. Berdasarkan pengujian hipotesis ini, didapatkan kesimpulan bahwa pendekatan konstruktivis melalui model pembelajaran kooperatif tipe STAD mempunyai pengaruh positif terhadap hasil belajar fisika materi Listrik Dinamis

Hal tersebut dikarenakan siswa yang dikenai pendekatan konstruktivis melalui model pembelajaran kooperatif tipe STAD dalam proses pembelajaran yang dilakukan mereka dapat mengerti konsep melalui pengkonstruksian konsep fisika.

\section{Lembar Pengamatan Siswa}

Penilaian kinerja ini terdiri dari 2 aspek yaitu aspek psikomotor dan aspek afektif. Hasil pengamatan aspek psikomotor dapat dituliskan pada tabel 7 sebagai berikut:

Tabel 7. Rata-rata aspek psikomotor

\begin{tabular}{|c|c|c|c|c|}
\hline Kelas & PBM 1 & PBM 2 & PBM 3 & Rata-rata \\
\hline Eksperimen 1 / $\mathrm{X}_{\mathrm{A}}$ & 2,75 & 2,76 & 2,78 & 2,76 \\
\hline Eksperimen 2 / $\mathrm{X}_{\mathrm{B}}$ & 2,65 & 2,67 & 2,66 & 2,66 \\
\hline
\end{tabular}

Dari data di atas dapat diketahui bahwa rata-rata aspek psikomotor pada kelas Eksperimen 2 yaitu kelas $\mathrm{X}_{\mathrm{B}}$ rendah yaitu sebesar 2,66 dibandingkan kelas Eksperimen yang lainnya yaitu kelas $\mathrm{X}_{\mathrm{A}}$ yang sebesar 2,76. Hal ini disebabkan karena pada kelas $X_{B}$ ini siswanya pada saat melakukan kegiatan percobaan kurang merespon dengan baik sehingga hasilnya rendah dibandingkan kelas Eksperimen $\mathrm{X}_{\mathrm{A}}$.

Dari data rata-rata aspek psikomotor tersebut dapat dibuat grafik batang seperti pada grafik 1 sebagai berikut:

Grafik 1. Hasil Pengamatan Aspek Psikomotor

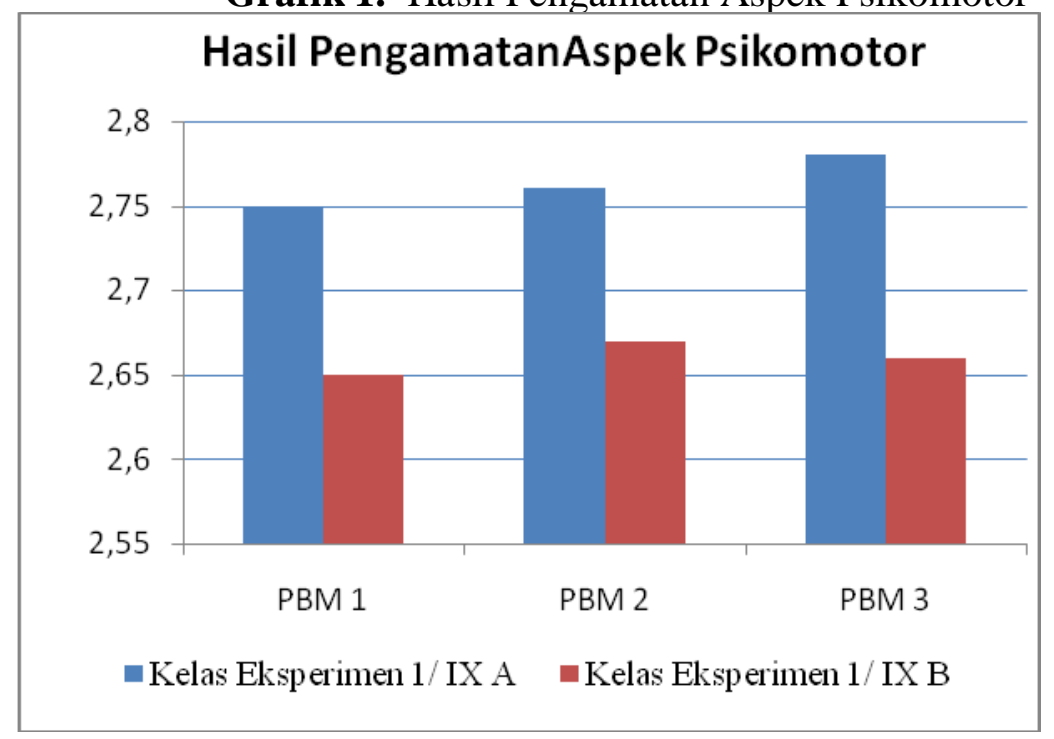

Dari grafik tersebut dapat diketahui bahwa pada Pembelajaran 1, 2 dan 3 kelas $X_{B}$ rata-rata aspek psikomotornya lebih rendah dibandingkan kelas eksperimen lainnya yaitu kelas $\mathrm{X}_{\mathrm{A}}$. Hasil pengamatan aspek Afektif dapat dituliskan pada tabel 8 sebagai berikut:

Tabel 8. Rata-rata Aspek Afektif siswa

\begin{tabular}{|c|c|c|c|c|}
\hline Kelas & PBM 1 & PBM 2 & PBM 3 & Rata-rata \\
\hline Kelas Eksperimen 1 / $\mathrm{X}_{\mathrm{A}}$ & 2,74 & 2,75 & 2,74 & 2,74 \\
\hline Kelas Eksperimen 2 / $\mathrm{X}_{\mathrm{B}}$ & 2,65 & 2,65 & 2,66 & 2,65 \\
\hline
\end{tabular}


Dari data di atas dapat diketahui bahwa rata-rata aspek afektif pada kelas Eksperimen 2 yaitu kelas $\mathrm{X}_{\mathrm{B}}$ lebih rendah yaitu sebesar 2,65 dibandingkan kelas Eksperimen yang lainnya yaitu kelas $\mathrm{X}_{\mathrm{A}}$ sebesar 2,74. Hal ini disebabkan karena pada kelas $X_{B}$ ini siswanya pada saat kegiatan pembelajaran berlangsung cenderung kurang disiplin sehingga hasilnya lebih rendah dibandingkan kelas Eksperimen yang lainnya.

Dari data di atas dapat dibuat grafik batang seperti pada grafik 2 sebagai berikut:

Grafik 2. Hasil Pengamatan Aspek Afektif

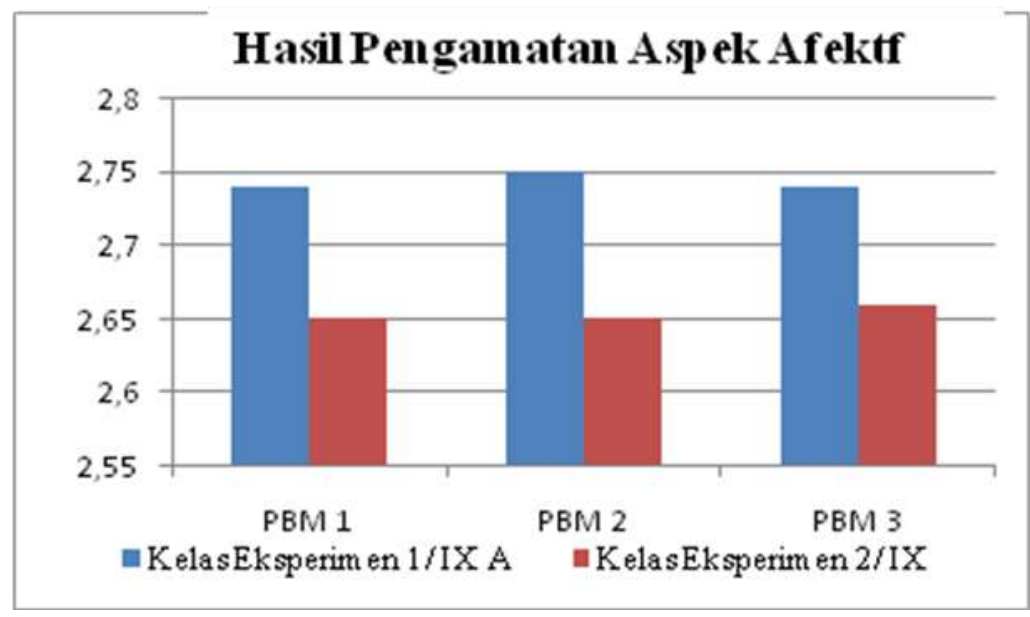

Dari grafik tersebut dapat diketahui bahwa pada Pembelajaran 1, 2 dan 3 kelas $\mathrm{X}_{\mathrm{B}}$ rata-rata aspek afektifnya lebih rendah dibandingkan kelas eksperimen $\mathrm{X}_{\mathrm{A}}$. Jadi dapat disimpulkan rata-rata aspek psikomotor dan afektif pada kelas $\mathrm{X}_{\mathrm{B}}$ lebih rendah yaitu sebesar 2,66 dan 2,65 dibandingkan dengan kelas eksperimen 2 $\mathrm{X}_{\mathrm{A}}$.

\section{Analisis Regresi.}

Berdasarkan nilai rata-rata kemampuan siswa aspek psikomotor dan aspek afektif, maka didapatkan rata-rata kemampuan kinerja siswa. Berdasarkan hasil posttest siswa, maka diperoleh kemampuan siswa pada aspek kognitif. Nilai rata-rata untuk 3 kelas Eksperimen dapat dituliskan dalam tabel 9 sebagai berikut:

Tabel 9. Nilai Kemampuan Kinerja dan Kemampuan Aspek Kognitif

\begin{tabular}{|c|c|c|c|c|}
\hline Kelas & $\begin{array}{c}\text { Aspek } \\
\text { Psikomotor }\end{array}$ & $\begin{array}{c}\text { Aspek } \\
\text { afektif }\end{array}$ & $\begin{array}{c}\text { Rata-rata } \\
\text { Kemampuan Kinerja } \\
\text { Siswa }\end{array}$ & $\begin{array}{c}\text { Rata-rata } \\
\text { Kemampuan } \\
\text { Kognitif siswa }\end{array}$ \\
\hline $\begin{array}{c}\text { Kelas Eksperimen 1 } \\
/ \mathrm{X}_{\mathrm{A}}\end{array}$ & 2,76 & 2,74 & 2,75 & 73,03 \\
\hline $\begin{array}{c}\text { Kelas Eksperimen 2 } \\
\text { / } \mathrm{X}_{\mathrm{B}}\end{array}$ & 2,66 & 2,65 & 2,66 & 68,44 \\
\hline
\end{tabular}

Cara menentukan regresi hubungan rata-rata kemampuan kinerja siswa terhadap rata-rata kemampuan siswa pada aspek kognitif adalah sebagai berikut:

\begin{tabular}{|c|c|c|c|r|r|}
\hline Kelas & $\begin{array}{c}\text { Variabel } \\
\text { Bebas (Xi) }\end{array}$ & $\begin{array}{c}\text { Variabel } \\
\text { Respon (Yi) }\end{array}$ & \multicolumn{1}{|c|}{$\mathrm{Xi} \mathrm{Yi}$} & $\mathrm{Xi}^{2}$ & \multicolumn{1}{c|}{$\mathrm{Yi}^{2}$} \\
\hline Kelas Eksperimen 1/ $\mathrm{X}_{\mathrm{A}}$ & 2,75 & 73,03 & 200,82 & 7,56 & 5332,80 \\
\hline Kelas Eksperimen 2/ $\mathrm{X}$ & 2,66 & 68,44 & 182,04 & 7,08 & 4683,35 \\
\hline Jumlah & 5,41 & 141,46 & 382,86 & 14,64 & 10016,15 \\
\hline
\end{tabular}

Dengan demikian didapatkan regresi $\hat{Y}=\mathrm{a}+\mathrm{b} \mathrm{X}$ berupa garis $\hat{Y}=-15+21,5 \mathrm{X}$. 
Hal ini terlihat dengan semakin tinggi ratarata kemampuan kinerja siswa, maka ratarata nilai kognitif siswa yang diperoleh dari hasil posttest adalah tinggi, dengan setiap rata-rata kemampuan kinerja siswa bertambah atau meningkat dengan satu tingkatan kemampuan, maka rata-rata kemampuan aspek kognitif juga bertambah atau meningkat sebesar 21,5.

\section{Korelasi Linier.}

Berdasarkan nilai kemampuan kinerja siswa akibat konstruktivisme dengan nilai kemampuan kognitif siswa, maka didapatkan koefisien korelasi sebagai berikut:

$$
\begin{aligned}
& r=\frac{0,43}{\sqrt{3600,42}}=\frac{1,828}{1,996}=0,9158 \\
& \text { atau } r^{2}=0,9102
\end{aligned}
$$

Berdasarkan hasil perhitungan koefisien korelasi di atas, diperoleh korelasi positif antara nilai kemampuan kinerja siswa dan nilai kemampuan kognitif siswa. Yang dimaksud adalah dengan adanya peningkatan kamampuan kinerja siswa, maka meningkat pula nilai kemampuan kognitif siswa. Besar hubungan peningkatan kemampuan kinerja siswa terhadap kemampuan aspek kognitif siswa ditentukan oleh koefisien determinasi $\mathrm{r}^{2}=$ 0,9102 atau sebesar $91,02 \%$. Hal ini berarti peningkatan atau penurunan kemampuan kinerja siswa melalui hubungan linier dengan persamaan: $\hat{Y}=-15+21,5 \mathrm{X}$

\section{Simpulan dan Saran \\ Simpulan}

Berdasarkan hasil analisis data penelitian, dapat disimpulkan bahwa:

- Pendekatan konstruktivis melalui model pembelajaran kooperatif tipe STAD berpengaruh positif terhadap pengkonstruksian konsep fisika berupa hasil belajar fisika materi Listrik Dinamis di kelas X SMA 2 Mojokerto.

- Aspek afektif dan aspek psikomotor dalam pengkonstruksian konsep fisika kelas eksperimen lebih baik dibanding dengan Aspek afektif dan aspek psikomotor kelas control.

\section{Saran}

Dari hasil penelitian yang diperoleh, maka peneliti memberikan saran agar penelitian berikutnya menjadi lebih baik yaitu terkait dengan kegiatan pengkonstruksian soal fisika disertai pengarahan yang jelas pada langkah-langkah pada contoh soal aplikasi. Kegiatan Siswa dapat difokuskan pada pengkonstruksian konsep sehingga siswa lebih mudah untuk memahami serta siswa lebih paham.

\section{Daftar Pustaka}

[1] Arikunto, Suharsini. 2002. Prosedur Penelitian. Jakarta: Rineka Cipta

[2] Bratanata, Juhara. 2007. Soal-Soal Uji Kompetensi Fisika SMA Kelas X. Bandung: CV Pustaka Setia.

[3] Departemen Pendidikan Nasional 2003. Kurikulum . Jakarta: Depdiknas.

[4] Nugroho, Djoko. 2002. Evaluasi Mandiri Fisika SMA untuk Kelas $X$.Jakarta: Penerbit Erlangga.

[5] Sardiman.1986.Perkembangan Kognitif.Bandung: Sinar Baru Algesindo

[6] Nur, M. Wikandari.2000. Pengajaran Berpusat Kepada Siswa dan Pendekatan Konstruktivis Dalam Pengajaran. Surabaya: University Press.

[7] Rohana. A 2004. Pembelajaran Dalam Implementasi Kurikulum Berbasis Kompetensi. Jakarta: Prenada Media.

[8] Suharsimi, Arikunto. 2002. DasarDasar Evaluasi Pendidikan. Jakarta: PT. Asdimahasatya.

[9] Sudjana, M.A. 1996. Metoda Statistika. Bandung: Tarsito.

[10] Sudjana, Nana. 2008. Dasar-dasar Proses Belajar Mengajar. Sinar Baru Algensindo: Bandung

[11]Tipler, Paul A.1991. Fisika Untuk Sains dan Teknik: Edisi Ketiga.Jakarta: Erlangga

[12] Kardi, M. Nur, M. 1999. Pengantar Pembelajaran dan Pengelolaan Kelas.Surabaya: University Press 